POLITICAL GROUPS IN CHILE

The Dialogue between Order and Change 
THIS PAGE INTENTIONALLY LEFT BLANK 
LATIN AMERICAN MONOGRAPHS, NO. 21 INSTITUTE OF LATIN AMERICAN STUDIES THE UNIVERSITY OF TEXAS AT AUSTIN 
THIS PAGE INTENTIONALLY LEFT BLANK 


\section{Political Groups in}

Chile the dialogue BETWEEN ORDER AND CHANGE by Ben G. Burnett

Published for the Institute of Latin American Studies by the University of Texas Press - Austin 
Copyright (C) I970 by Ben G. Burnett

First paperback printing 2015

All rights reserved

Printed in the United States of America

Requests for permission to reproduce material from this work should be sent to:

Permissions

University of Texas Press

P.O. Box 78 I 9

Austin, TX 78713-78I9

http://utpress.utexas.edu/index.php/rp-form

Library of Congress Catalog Number 70-I 35759

ISBN 978-I-4773-0572-0, paperback

ISBN 978-I-4773-0573-7, library e-book

ISBN 978-I-4773-0574-4, individual e-book 
TO MY PARENTS,

Cora S. and Ben H. Burnett

AND TO MY PARENTS-IN-LAW,

Ingrid S. and J. Scott Jensen 
THIS PAGE INTENTIONALLY LEFT BLANK 